\title{
Yerel Halkın Milli Parklara Yönelik Çevresel Kimlik, Çevresel Tutum ve Katılım Yaklaşımları
}

Local People's Environmental Identity, Environmental Attitude and Participation Approaches towards National Parks

\author{
Çetin AKKUŞ*, Selda YORDAM** \\ * (Sorumlu Yazar) Dr. Öğr. Üyesi, Kastamonu Üniversitesi, Turizm Fakültesi Turizm İşletmeciliği Bölümü, Kuzeykent, Orgeneral Atilla Ateş Paşa Cd. No: 15/A, 37150 \\ Sarı̈mer, Kastamonu. \\ E-posta: cakkus@kastamonu.edu.tr \\ ORCID: 0000-0002-6539-726X \\ ** Arş. Gör., Kastamonu Üniversitesi, Turizm Fakültesi Turizm İşletmeciliği Bölümü, Kuzeykent, Orgeneral Atilla Ateş Paşa Cd. No: 15/A, 37150 Sarı̈mer, \\ Kastamonu. \\ E-posta: syordam@kastamonu.edu.tr \\ ORCID: 0000-0001-8126-5817
}

\section{MAKALE BILGILERI}

Makale işlem bilgileri:

Gönderilme tarihi:13 Şubat 2021

Düzeltme: 19 Nisan 2021

Kabul: 24 Nisan 2021

Anahtar sözcükler: Çevresel kimlik, Çevresel tutum, Katılım, Milli parklar, Kastamonu.

\section{ARTICLE INFO}

Article history:

Submitted: 13 February 2021

Resubmitted: 19 April 2021

Accepted: 24 April 2021

Key words: Environmental identity, Environmental attitude, Participation, National parks, Kastamonu.

\begin{abstract}
ÖZ
Milli parklar sahip olduğu doğal ve kültürel değerler yönüyle korunması gereken alanlar arasında bulunmaktadır. Bu alanların sürdürülebilirliğini sağlamak, ekosistemlerini ve biyolojik çeșitliliğini başarılı bir şekilde korumak için yerel halkın katılımı önem arz etmektedir. Türkiye'de toplam 45 milli park bulunmaktadır. Kastamonu ise bu parkların üçüne ev sahipliği yapmaktadır. Bu araştırmada, milli parklara yönelik çevresel kimlik, çevresel tutum ve katılım ilişkisinin Yapısal Eşitlik Modellemesi ile çözümlenmesi amaçlanmıştır. Bu amaç doğrultusunda Kastamonu yerel halkından kolayda örnekleme yöntemiyle 399 katılımcıya ulaşılmış ve anket uygulanmıştır. Analizler sonucunda çevresel kimliğin çevresel tutumu, çevresel tutumun da katılımı etkilediği tespit edilmiștir. Bununla beraber yerel halkın doğal alanları ziyaret etme sıklığı, doğa koruma derneğine üye olma durumu, memleketi ve ilde yaşama süresinin çevresel kimlik, çevresel tutum ve katılım boyutlarına göre istatistiksel açıdan anlamlı farklııklar gösterdiği tespit edilmiştir.
\end{abstract}

\begin{abstract}
National parks are among the areas that should be protected in terms of their natural and cultural values. Participation of local people is important to ensure the sustainability of these areas and to protect their ecosystems and biodiversity successfully. There are $\mathbf{4 5}$ national parks in Turkey. Kastamonu is home to three of these parks. In this study, it is aimed to analyze the relationship between environmental identity, environmental attitude and participation towards national parks with Structural Equation Modeling. For this purpose, 399 participants from Kastamonu local people were reached using the convenience sampling method and a questionnaire was applied. As a result of the analysis, it was determined that environmental identity affects environmental attitude and environmental attitude affects participation. However, it was determined that the frequency of visiting natural areas of the local people, the status of being a member of the nature conservation association, their hometown and the duration of life in the province showed statistically significant differences according to environmental identity, environmental attitude and participation dimensions.
\end{abstract}

\section{Giriş}

Milli parklar ender bulunan doğal, kültürel ve rekreasyonel değerleri koruma amacı taşıyan coğrafi alanlardır. Türkiye'de toplam 45 milli park bulunmaktadır (Tarım ve Orman Bakanlığı 2021). Kastamonu ili Ilgaz Dağı Milli Parkı, Küre Dağları Milli Parkı ve İstiklal Yolu Milli Parkı olmak üzere üç milli parka ev sahipliği yapmaktadır. Ilgaz Dağı Milli Parkı, 1976 yılında milli park ilan edilmiştir. Park birçok yaban hayatı türlerine uygun yaşama ortamı sağlamakla (Erdoğan 2003) birlikte doğa yürüyüşü, fotoğrafçılık, yaban hayatı gözlemciliği, dağcilık ve kayak gibi aktivitelere de imkân tanımaktadır (Doğa Koruma ve Milli Parklar Müdürlüğü 2020). 2000 
yılında envantere dâhil edilen Küre Dağları Milli Parkı ise özellikle yaban hayatı yönünden zengin olup, doğa yürüyüşleri, tırmanma ve rekreasyonel faaliyetlere imkân tanımaktadır (Erdoğan 2003). Ayrica 2012 yılında yaban alanları korumak için Avrupa'nın seçkin korunan alanları ağı olan PAN Parks sertifikasını alarak, Türkiye'nin ilk panparkı ilan edilmiştir (Küre Dağları Milli Parkı 2020). 2018 yılında milli park statüsü kazanan İstiklal Yolu Milli Parkı ise Kurtuluş Savaşı boyunca silah ve erzakların cephelere ulaştırılmasında bir yol olarak kullanılmasından dolayı (Doğa Koruma ve Milli Parklar Müdürlüğü 2020) günümüzde birçok anma etkinliğinin merkezi olmuştur.

Doğal alanların gelişmesi, korunması ve yönetilmesi aşamalarında topluluk katılımı başarıya ulaşmada kilit rol oynamaktadır (Shrestha ve Alavalapati 2006). Korunan alanların sürdürülebilirliğini sağlamak, ekosistemlerini ve biyolojik çeşitliliğini başarılı bir şekilde korumak için yerel halkın desteği hayati önem taşımaktadır (Sirivongs ve Tsuchiya 2012). Dolayısıyla sürdürülebilirliğin sağlanması açısından korunması gereken alanlardan olan milli parkların öncelikle bölgede yaşayan yerel halk tarafından benimsenmesi önem arz etmektedir. Böylelikle kapsayıcı bir çevresel kimlik gelişecek olup, bu durum önce olumlu tutum geliştirmeyi daha sonra ise korumaya katılımın gerçekleşmesini sağlayacaktır.

Uluslararası alanyazında yerel halkın katılımının önemli bir yer tuttuğu görülmektedir. (Tukamushaba ve Okech 2011). Korunan alanlarda yerel halkın katılımı hususunda politikalar belirlenmesi (Bakır 2019) park yönetimine ve planlamasına yerel halkın dahil edilmesi parkların gelişimine katkı sağlayabilir (Ezebilo ve Mattsson 2010). Türkiye'de birçok korunan alan bulunmaktadır. Bu alanlarda yapılacak çalışmalar sayesinde yerel halkın doğal alanları koruma düzeyinin geliştirilmesine katkı sağlanabilir. Bu doğrultuda araştırmanın amacl, yerel halkın milli parklarla ilgili çevresel kimlik, çevresel tutum ve katılım arasındaki ilişkisini ortaya koymaktır. Ayrıca yerel halkın doğa koruma derneğine üye olma durumu, doğal alanları ziyaret etme sıklığı, memleket durumu ve ilde yaşama sürelerinin bu üç değişkene göre farklılık gösterip göstermediği belirlenmeye çalışılmıştır. Bu sebeple çalışmanın alanyazına katkı sağlayacağı ve destinasyon yöneticilerine milli parklarla ilgili yerel halkın yaklaşımları hakkında fikir sağlayacağı düşünülmektedir.

\section{KAVRAMSAL ÇERÇEVE}

\section{Çevresel Kimlik}

Çevresel kimlik kavramı, bireyin çevreye yönelik davranışlarının motivasyonu olarak ortaya çıkmıştır (Kashima vd. 2014). Bu kavram çevreyle ilişkili olarak bireyin kendine yorduğu anlam olarak ifade edilmektedir (Stets ve Biga 2003). Başka bir deyişle, kişinin çevre ile etkileşime girdiği zaman kendiyle bağdaştırdığı anlamlar olarak nitelendirilmektedir. Örneğin, kamp gezileri, yürüyüşler ve doğada hayvanları gözlemlemek gibi yapılan aktiviteler birey için doğal ortamın kendisine ne anlam ifade ettiği ve bu ortamın nasıl yorumladı $\breve{g}_{1}$ hakkında deneyimler sağlamaktadır (Lake 2019). Bunun yanı sıra, çevresel kimlik kişinin kendini doğanın bir parçası olarak görüp görmediğini yansıtmaktadır (Van der Werff vd. 2013). Kendisini doğal çevrenin bir parçası olarak gören kişiler daha güçlü bir çevresel kimliğe sahip olurken, kendisini doğal ortamdan ayrı görenler ise daha zayıf bir çevre kimliğine sahip olmaktadır (Lake 2019). Buradan çıkarımla çevresel kimlik birey ve çevre arasındaki ilişkiyi incelemek için önemli görülmektedir.

Çevresel kimlik fikri, benlik ve çevre sorunları arasındaki etkileşimin görülmesini sağlamaktadır (Clayton 2003). Ayrıca bu fikir, doğal çevreye özen göstermeye ve çevrenin korunmasına teşvik etmektedir (Clayton ve Opotow 2003). Kempton ve Holland (2003) çevreciler arasında çevresel kimlik sürecinin üç aşamada gerçekleştiğini belirtmiştir. Farkında olma aşamasında, kişi çevresel sorunlar ve tehditler hakkında bilinçli hale gelmektedir. İkinci aşamada, birey kendini çevresel faaliyetlerde katılımcı olarak görmektedir. Son aşamada ise, birey çevre hareketinin nasıl gerçekleştiği ve çevresel faaliyetlere nasıl dâhil olunacağı hakkında bilgi sahibi olmaktadır. 


\section{Çevresel Tutum}

Doğal kaynakların hızla tükenmesi ekolojik kaygıları ortaya çıkarmaktadır. Bu kaygı ile birlikte birey ve doğal çevre ilişkisini açıklamak için çevresel tutum kavramı kullanılmaya başlanmiştır (Milfont ve Duckitt 2004). Çevresel tutum bireylerin çevre ile ilgili faaliyetler veya konular hakkında sahip olduğu inanç, duygu ve davranış niyetlerinin bütünü olarak tanımlanmaktadır (Schultz vd. 2004). Bir başka ifadeyle bireyin kendisi dâhil kişiler, nesneler ve sorunlar hakkında nasıl düşündügüu veya hissettiğidir (Eliam ve Trop 2012).

Çevresel tutumlar çoğu zaman çevre kalitesini artıran veya azaltan davranışların belirlenmesi açısından önemli görülmektedir (Gifford ve Sussman 2012). Milfont ve Duckitt (2006) çevresel tutumu kategorilere ayırmıştır. Bunlar; doğadan zevk alma, müdahaleci koruma politikalarına destek, çevre hareketi, insan merkezli kaygıyla motive edilen koruma, bilim ve teknolojiye güven, çevresel tehdit, doğayı değiştirmek, kişisel koruma davranışı, doğa üzerinde insan egemenliği ve çevre merkezli endişe olarak belirtilmektedir (Milfont ve Duckitt 2006 aktaran Abun ve Racoma 2017).

\section{Katılım}

Katılım, bireylerin yaşadıkları destinasyonu geliştirmek için toplumun gereksinimlerini dikkate alarak yeniden dizayn etmesi olarak ifade edilmektedir. Bu durum bir kalkınma stratejisi olarak topluluk katılımının topluluk kaynaklarına, ihtiyaçlarına ve kararlarına dayanmaktadır (Tosun 2000: 615). Yerel halk, turizm kaynaklarının belirlenmesine ve bu kaynakların onlara fayda sağlamak için nasıl geliştirilebileceğine katılım sağlamalıdır (Tukamushaba ve Okech 2011). Tüm faaliyetlerden elde edilen genel yararı en üst düzeye çıkarmak için toplum katılımı kritik önem taşır (Lewis 2015). Toplum üyeleri grup içinde önemli rol oynadıklarını algıladığında, yüksek düzeyde öz sorumlulukları bir kimlik duygusunun oluşumuna teşvik eder, bu durumda toplumdaki bireylerin davranışlarına yansır (Bagozzi ve Dholakia 2002). Yani yerel halk organizasyonlara ya da etkinliklere aktif olarak katıldı̆̆ında çevresel so- runlara karşı daha aktif ve sorumlu bir yaklaşım sergilemektedir (Cheng vd. 2019). Bu doğrultuda korunan alanlarla ilişkin etkin ve başarılı turizm planlaması ve yönetimi için yerel halkın katılımına ihtiyaç bulunmaktadır (Bello vd. 2016).

\section{ILGILI ÇALIŞMALAR}

Alanyazında çevresel kimlik, çevresel tutum ve katılım kavramlarına yönelik çalışmalar bulunmasına rağmen, kavramlar arasındaki ilişkiyi ya da etkiyi ölçmeye yönelik araştırmaların oldukça sinırlı olduğu görülmüştür. Su vd. (2019) yerel halk ve çevre ilişkisini ölçmek için çevresel kimlik ve çevresel bağlılık değişkenlerini kullanmıştır. Çalışmada destinasyonun çevre kalitesi ve çevre dostu itibarının, yerel halkın çevresel kimliği ve çevre bağlılı̆̆ını etkilediği sonucuna ulaşılmıştır. Ayrıca çevresel kimliğin çevreye duyarlı davranışı etkilediği tespit edilmiştir. Yer kimliği, toplum duyusu ve çevresel tutumun ele alındığı çalışmada, kimliğin çevresel tutumu etkilediği görülmüştür (Kutay Karaçor ve Akçam 2016). Bir diğer çalışmada çevresel kimliğin, ekoturizm tutum ve davranışlarını açıklamadaki rolü ve doğrudan bir etkiye sahip olup olmad1ğ1 belirlenmeye çalışılmıştır. Çalışmada çevresel kimliğin ekoturizm üzerinde doğrudan ve olumlu bir etkiye sahip olduğu sonucuna ulaşılmıştır (Teeroovengadum, 2019). Benzer şekilde Stets ve Biga (2003) ve Hinds ve Spark (2008) yaptıkları çalışmalarda çevresel kimliğin çevresel tutum üzerinde güçlü bir etkiye sahip olduğuna ulaşmıştır. Bu bağlamda ilgili alanyazına dayanılarak aşağıdaki hipotez öne sürülmüştür.

H1: Çevresel kimliğin çevresel tutum üzerinde etkisi vardir.

Wang ve Yamamoto (2009) yerel halkın doğal kaynaklara ilişkin tutum ve katılım algısını belirlemeye çalışmıştır. Çalışma sonuçlarına göre olumlu katılım, yerel halkın doğal kaynaklara yönelik algılarını ve tutumlarını olumlu bir şekilde etkilemektedir. Cheng vd. (2019) çalışmasında yerel halkın sürdürülebilir turizm gelişimine yönelik tutumlarının hem katılımı hem de çevreye duyarlı davranışı olumlu ve önemli ölçüde etkilediğini tespit etmiştir. Sirivongs ve Tsuchiya 
(2012) ise yerel halkın ulusal korunan alanlara yönelik algı, tutum ve katılımını incelediği araştırmasında, tutumun katılım üzerinde güçlü bir etkiye sahip olduğu sonucuna ulaşmıştır. Alanyazına bakılarak, tutum ile katılım arasında bağlantı olduğu görülmüştür. Bu doğrultuda aşağ1daki hipotez öne sürülmüştür.

\section{H2: Çeoresel tutumun katılım üzerinde etkisi vardır.}

\section{YÖNTEM}

\section{Araştırmanın Amacı}

Kastamonu sınırları içerisinde bulunan üç milli parkın ikisi doğal güzellikleri ve biyoçeşitliliği ile ön plana çıkarken, bir diğeri tarihi olarak önemli bir yere sahiptir. Bu araştırmada yerel halkın milli parklara yönelik çevresel kimlik, çevresel tutum ve katılım arasındaki ilişkilerin bütünleşik olarak yapısal eşitlik modellemesiyle araştırılması amaçlanmıştır. Araştırma amacı doğrultusunda geliştirilen model Şekil 1'de verilmiştir.

Bununla birlikte, çevreye yönelik yapılan çalışmalarda demografik değişkenlerin farklılık gösterdiği bilinmektedir (Prévot vd. 2018). Nitekim bu çalışmada yerel halkın çevresel kimlik, çevresel tutum ve katılımının çeşitli durumlara göre farklılaşıp farklılaşmadığ mıştır. Bu doğrultuda dört araştırma sorusu ortaya konulmuştur:

1. Yerel halkın çevresel kimlik, çevresel tutum ve katılımı doğal alanları ziyaret etme sıklığına göre farklılık gösteriyor mu?

2. Yerel halkın çevresel kimlik, çevresel tutum ve katılımı doğa koruma derneği üye olma durumuna göre farklılık gösteriyor mu?

3. Yerel halkın çevresel kimlik, çevresel tutum ve katılımı memleket durumuna göre farklılık gösteriyor mu?

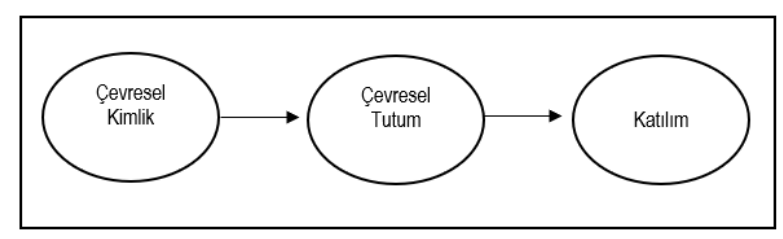

Şekil 1. Araştırma Modeli
4. Yerel halkın çevresel kimlik, çevresel tutum ve katılımı Kastamonu'da yaşama sürelerine göre farklılık gösteriyor mu?

\section{Araştırmanın Evreni ve Örneklemi}

Araştırma evrenini Kastamonu'da yaşayan yerel halk oluşturmaktadır. Araştırma evreninin Kastamonu seçilme sebebi, doğal ve tarihi açıdan öneme sahip üç milli parka ev sahipliği yapmasıdır. Evrenin tamamına ulaşmak zaman ve maliyet açısından mümkün olmadığı için örnekleme yoluna gidilmiştir. Araştırmada tesadüfi olmayan örnekleme yöntemlerinden kolayda örnekleme tercih edilmiştir. Bu yöntem, gerek pandemi sürecinde veri toplamanın zorlukları gerekse çevrimiçi olarak toplanan anketlerin geri dönüş oranının düşüklüğü göz önüne alınarak, yeterli örneklem düzeyine ulaşabilmek için tercih edilmiştir. Çalışma kapsamında Kastamonu'da en az bir yıldır yaşayan bireylere ulaşılmıştır. Google form üzerinden oluşturulan anket formu sosyal medya platformlarindan (facebook, instagram, whatsapp) paylaşılmıştır. Araştırma verileri çevrimiçi olarak 28.12.2020-10.01.2021 tarihler arasında elde edilmiştir. Çalışmanın yüzde 95 güven aralığında ve 0,05 anlamlılık seviyesinde toplam 384 kişiye yapılması uygun görülmüştür (Altunışık vd. 2012: 137). Çalışma için toplam 399 anket formu değerlendirmeye alınmıştır.

\section{Veri Toplama Tekniği}

Nicel araştırma yöntemlerine dayanan bu çalışmada tarama deseni kullanılmıştır. Tarama araştırmaları kişilerin belli bir konudaki tutum, davranış, görüş ve beklentilerini anket aracıl1ğıyla tespit etmeyi hedefleyen araştırmalardır (Gürbüz ve Şahin 2018: 105). Anket formu iki bölümden oluşmaktadır. Birinci bölüm çevresel kimlik, çevresel tutum ve katılım ölçeklerini içermektedir. Ölçek ifadeleri için beşli likert tipi (1=Kesinlikle Katılmiyorum, 5= Kesinlikle Katıl1yorum) kullanılmıştır. Anketin ikinci bölümünde ise katılımcıların demografik özelliklere ilişkin 10 soruya yer verilmiştir. Anket formunun birinci bölümünde yer alan ve beş ifadeden oluşan çevresel kimlik ölçeği için So vd. (2013) çalışmasindan, dört ifadeden oluşan tutum ölçeği ve beş 
ifadeden oluşan katılım ölçeği için Sirivongs ve Tsuchiya (2012) çalışmasından yararlanılmıştır. Bu çalışmalarda kullanılan ölçeklerin geçerlik ve güvenirlik katsayılarının yeterli düzeyde olduğu tespit edilmiştir (Gürbüz ve Şahin 2018).

\section{BULGULAR}

Katılımcılara ilişkin bulgulara bakıldığında; yüzde 53,6'sı kadın, yüzde 35,8'i 18-25 yaş aralığında, yüzde 51,9'unun bekâr, yüzde 36,1'inin lisans düzeyi ve yüzde 34,6' sinın 2325-5000 TL arasında gelirinin olduğu görülmektedir. Ayrıca katılımcıların yüzde 10'unun bir doğa koruma derneğine üye olduğu, çevresinde bulunan kişilerin büyük çoğunluğunun (yüzde 72,7) çevreyi korumakla ilgilendiği ve yüzde 55,4'ünün doğal alanları ayda bir ya da daha fazla ziyaret ettiği tespit edilmiştir. Bunun yanı sıra katılımcıların çoğunluğunun (yüzde 73,7) Kastamonulu olduğu ve yüzde 65,7' sinin 10 yıldan fazladır Kastamonu'da yaşadığı görülmüştür.

Araştırma verileri incelendiğinde çevresel kimlik $(-, 866 ; 380)$ ve katılımin $(-1,135 ; 1,888)$ normal dağılım gösterdiği, tutum ölçeğinin ise $(-1,643$; $4,149)$ normal dağılım göstermediği belirlenmiştir (Gürbüz ve Şahin 2018: 211).

\section{Araştırma Modelinin Test Edilmesi}

Yapısal eşitlik modellemesi ile hipotezler test edilmeden önce SPSS Amos programı aracılığıyla modelin eldeki veri seti ile uyumunu ortaya koymak için modele ilişkin uyum iyiliği istatistikleri değerlendirilmiştir. Tablo 1'de sunulan değerlere göre, yapısal modelin kabul edilebilir değerlere sahip olduğu görülmektedir (Hair vd. 2009: 649).

Çalışmaya ilişkin CR ve AVE değerlerine Tablo 2 'de yer verilmiştir. Ölçekte yer alan iki ifadenin faktör yükleri 0,50 'nin altında kaldığ için analizlerden çıkarılmıştır ve tabloda gösterilmemiştir. Ölçeklerin tümünde $C R$ değerinin 0,70 'in üzerinde, AVE değerlerinin ise 0,50'nin üzerinde olduğu görülmektedir. Dolayısıyla ölçeklerin yapı güvenirliğine ve birleşim geçerliliğine sahip olduğu söylenebilir (Gürbüz 2019: 78).

Yerel halkın çevresel kimlik ölçeğine ilişkin genel ortalama değeri beş üzerinden 3,70 çevresel
Tablo 1. Araştırma Modeli Uyum İndeksleri

\begin{tabular}{|c|c|c|}
\hline $\begin{array}{l}\text { Uyum Iyiliği } \\
\text { Indeksleri }\end{array}$ & Kabul Edilebilir Uyum & Model \\
\hline$\chi^{2}$ & - & 135,351 \\
\hline $\mathrm{df}$ & - & 49 \\
\hline$\chi 2 / d f$ & $1-3$ & 2,762 \\
\hline GFI & $\geq 0,90$ & 0,949 \\
\hline AGFI & $\geq 0,85$ & 0,919 \\
\hline $\mathrm{CFI}$ & $\geq 0,90$ & 0,965 \\
\hline RMSEA & $0,03 \leq \mathrm{RMSEA} \leq 0,08$ & 0,067 \\
\hline RMR & $0 \leq \mathrm{RMR} \leq 1$ & 0,045 \\
\hline NFI & $0 \leq \mathrm{NFI} \leq 1$ & 0,946 \\
\hline
\end{tabular}

tutum ölçeğinin 3,99 katılımın ise 4,00 olarak ölçülmüştür.

Modelin herhangi bir iyileştirmeye gereksinimi olup olmadığını anlamak amacıyla modifikasyon indeksi incelenmiş ve modelin bu haliyle kalması uygun bulunmuştur. Bu aşamanın ardından modelde yer alan boyutlar arasındaki ilişkiler, sunulan hipotezler çerçevesinde test edilmiştir. Önerilen modele ait path analizi Şekil 2'de sunulmuştur.

Önerilen model için yol analizi tahminlerine ait değerler Tablo 3'te sunulmuştur. Path analizi sonucunda $\mathrm{H} 1$ hipotezini ifade eden yapısal ilişki, tahminin var olan veri ile desteklendiğini göstermiştir. Çevresel kimliğin çevresel tutum üzerinde anlamlı ve pozitif bir etkisinin olduğu belirlenmiştir. Buna göre yerel halkın milli parkların gelişimi ve yerel halka fayda sağlaması açısından tutumlarının olumlu etkilendiği söylenebilir. Bu sonuçlar doğrultusunda "Çevresel kimliğin çevresel tutum üzerinde etkisi vardır." şeklinde kurulan $\mathrm{H}_{1}$ hipotezi kabul edilmiştir.

Çevresel tutumun katılım üzerindeki etkisine bakıldığında 0,001 önem düzeyinde anlamlı pozitif bir etkiye sahip olduğu görülmüştür. Yani yerel halkın milli parklarla ilgili gönüllük esas1na dayanan görevlerde ve eğitimlerde yer almak istemeleri katılımlarını olumlu yönde etkilemektedir. Bu doğrultuda "Çevresel tutumun katılım üzerinde etkisi vardır." şeklinde kurulan $\mathrm{H}_{2}$ hipotezi kabul edilmiştir. 
Tablo 2. Ölçeklere İlişkin CR ve AVE Değerleri

\begin{tabular}{|c|c|c|c|c|c|}
\hline \multirow{7}{*}{$\frac{\text { Ölçekler }}{\text { Çevresel Kimlik }}$} & \multicolumn{2}{|c|}{ Faktör Yükü } & \multirow{3}{*}{ Ort. } & \multirow{2}{*}{$\frac{A V E}{0,568}$} & \multirow{2}{*}{$\begin{array}{r}C R \\
0,867\end{array}$} \\
\hline & & & & & \\
\hline & $\begin{array}{l}\text { Kastamonu'daki milli parklar hakkında başkalarının } \\
\text { ne düşündükleriyle çok ilgilenirim. }\end{array}$ & & & 0,729 & 3,48 \\
\hline & Kastamonu'daki milli parkların başarısı benim başarımdır. & 0,720 & 3,47 & & \\
\hline & $\begin{array}{l}\text { Kastamonu'daki milli parklardan bahsettiğim zaman, } \\
\text { o parklar yerine bizim milli parklarımız derim. }\end{array}$ & 0,743 & 3,91 & & \\
\hline & $\begin{array}{l}\text { Birisi Kastamonu'daki milli parkları övdüğünde kişisel } \\
\text { bir iltifat almış gibi hissederim. }\end{array}$ & & & 0,835 & 3,96 \\
\hline & $\begin{array}{l}\text { Birisi Kastamonu'daki milli parkları eleştirdiğinde mahcup } \\
\text { hissederim. }\end{array}$ & 0,738 & 3,69 & & \\
\hline \multirow[t]{4}{*}{ Çevresel Tutum } & & & 3,99 & 0,560 & 0,79 \\
\hline & $\begin{array}{l}\text { Kastamonu'daki milli parklarımızın gelişimini fazlasıyla } \\
\text { desteklerim. }\end{array}$ & 0,835 & 4,32 & & \\
\hline & $\begin{array}{l}\text { Kastamonu'daki milli parklar yerel topluma birçok fayda } \\
\text { sağlar. }\end{array}$ & 0,766 & 4,17 & & \\
\hline & $\begin{array}{l}\text { Kastamonu'daki milli parklardan sağlanan fayda, yerel } \\
\text { halkla da paylaşılmalıdır. }\end{array}$ & 0,631 & 4,29 & & \\
\hline \multirow[t]{5}{*}{ Katılım } & & & 4,00 & 0,595 & 0,854 \\
\hline & $\begin{array}{l}\text { Kastamonu'daki milli parklar ile ilgili görevlere katılmak } \\
\text { isterim. }\end{array}$ & 0,798 & 3,82 & & \\
\hline & $\begin{array}{l}\text { Kastamonu'daki milli parkların gelişimi için verilen } \\
\text { kararlarda katılım hakkımız olduğunu düşünüyorum. }\end{array}$ & 0,801 & 3,99 & & \\
\hline & $\begin{array}{l}\text { Eğer firsat olursa, ilgili herhangi bir eğitim kursuna katılmak } \\
\text { isterim. }\end{array}$ & 0,757 & 3,73 & & \\
\hline & $\begin{array}{l}\text { Uygun operasyon ve yönetim olursa gönüllü işlere katılmak } \\
\text { isterim (çöp toplamak, ağaç dikmek) }\end{array}$ & 0,728 & 4,01 & & \\
\hline
\end{tabular}

Çevresel kimlik ve katılımın katılımcıların doğa koruma derneğine üye olma durumlarına göre anlamlı farklılık gösterip göstermediğini belirlemek için parametrik test yöntemi olan bağımsız örneklem $\mathrm{t}$ testi uygulanmıştır. Levene test değerleri incelendiğinde, çevresel kimlik ve katılım ölçeklerinin 0,05 anlamlılık düzeyinin üzerinde olduğu belirlenmiştir (çevresel kimlik 0,824; katılım 0,601). Analiz sonucunda yerel halkın katılımının doğa koruma derneği üye olma durumuna göre farklılaştı̆̆ $t=2,022)$. Doğa koruma derneğine üye olan katılımcıların, üye olmayanlara göre katılıma daha duyarlı oldukları söylenebilir. Diğer yandan çevresel kimliğin doğa koruma derneği üye olunmasına göre farklılaşmadığ 1 belirlenmiştir $(p=0,871$; $\mathrm{t}=0,163)$. Çevresel tutum ile doğa koruma derneğine üye olma arasında fark olup olmadığını belirlemek için non-parametrik test yöntemi olan Mann-Whitney U testi uygulanmıştır. Test sonucu incelendiğinde, çevresel tutum doğa koruma derneği üye olma durumuna göre anlamlı farklılık göstermemektedir ( $\mathrm{p}=0,808)$.

Çevresel kimlik ve katılımın katılımcıların memleket durumlarına göre farklılaşıp farklılaşmadığını belirlemek için bağımsız örneklem t testi yapılmıştır. Levene test değerleri incelendiğinde, çevresel kimlik ve katılım ölçeklerinin homojen dağılım gösterdiği saptanmıştır $(0,528$; $0,443)$. Analiz sonucunda çevresel kimliğin memleket durumuna göre farklılaştı̆̆ tir ( $p=0,000 ; t=4,245)$. Bu durum memleketi Kasta- 


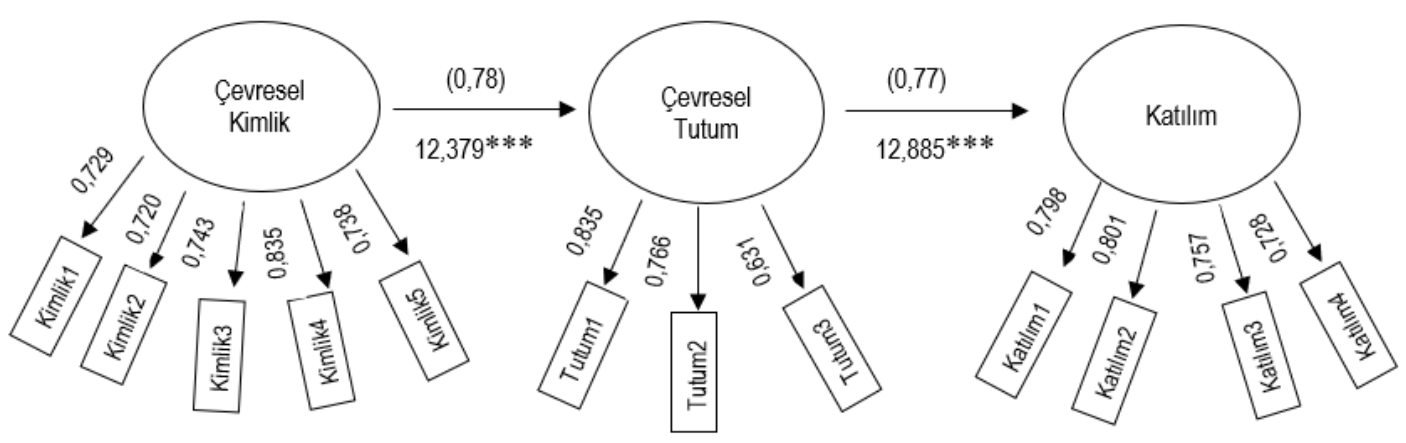

Şekil 2. Araştırma Modeline İlişkin Path Analizi

Tablo 3. Önerilen Model İçin Yol Analizi Tahminleri

\begin{tabular}{|c|c|c|c|c|c|c|c|c|c|}
\hline$H$ & Yapısal ilişs & & Yön & 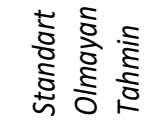 & 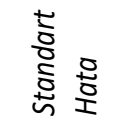 & 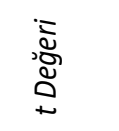 & 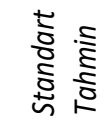 & $P$ & Sonuç \\
\hline $\mathrm{H}_{1}$ & $\begin{array}{l}\text { Çevresel Kimlik } \\
\text { Çevresel Tutum }\end{array}$ & $\longrightarrow$ & Pozitif & 0,62 & 0,50 & 12,379 & 0,78 & $* * *$ & Kabul \\
\hline $\mathrm{H}_{2}$ & $\begin{array}{l}\text { Çevresel Tutum } \\
\text { Katılım }\end{array}$ & $\longrightarrow$ & Pozitif & 0,83 & 0,65 & 12,885 & 0,77 & $* * *$ & Kabul \\
\hline
\end{tabular}

$* * * \mathrm{p}<0,001$

Tablo 4. Çevresel Kimlik, Çevresel Tutum ve Katılım ile Doğal Alanları Ziyaret Etme Sıklığı Arasındaki Farklılıklara İlişkin ANOVA ve Kruskal-Wallis Testleri

\begin{tabular}{|c|c|c|c|c|c|c|c|}
\hline Değişkenler & Ziyaret Etme Sıklığı & $N$ & Ort. & $\begin{array}{c}\text { Std. } \\
\text { Sapma }\end{array}$ & $F$ & $\begin{array}{c}\text { ANOVA } \\
\text { Anlamlılık }\end{array}$ & Farklılık \\
\hline \multirow{3}{*}{$\begin{array}{l}\text { Çevresel } \\
\text { kimlik }\end{array}$} & Yılda bir veya daha az & 44 & 3,3909 & 1,09795 & \multirow{3}{*}{3,974} & \multirow{3}{*}{$0,020 *$} & \multirow{3}{*}{$1<3$} \\
\hline & Yılda birkaç kez & 134 & 3,6418 & ,89781 & & & \\
\hline & Ayda bir veya daha fazla & 221 & 3,8127 & ,97990 & & & \\
\hline \multirow{4}{*}{ Katılım } & Yılda bir veya daha az & 44 & 3,5091 & ,92556 & \multirow{3}{*}{15,187} & \multirow{3}{*}{$0,000^{*}$} & $1<2$ \\
\hline & Yılda birkaç kez & 134 & 3,9194 & ,71382 & & & $1<3$ \\
\hline & Ayda bir veya daha fazla & 221 & 4,1629 & ,74167 & & & $2<3$ \\
\hline & Ziyaret Etme Sıklığı & $\mathrm{N}$ & Sıra Ort. & S.D. & $x^{2}$ & $\begin{array}{l}\text { Kruskal- } \\
\text { Wallis } \\
\text { Anlamlılık }\end{array}$ & Farklılık \\
\hline \multirow{3}{*}{$\begin{array}{l}\text { Çevresel } \\
\text { tutum }\end{array}$} & Yılda bir ya da daha az & 44 & 163,06 & \multirow{3}{*}{2} & \multirow{3}{*}{8,629} & \multirow{3}{*}{$0,013^{*}$} & \multirow{3}{*}{$1<3$} \\
\hline & Yılda birkaç kez & 134 & 190,09 & & & & \\
\hline & $\begin{array}{l}\text { Ayda bir ya da daha } \\
\text { fazla }\end{array}$ & 221 & 213,36 & & & & \\
\hline
\end{tabular}


Tablo 5. Çevresel Kimlik, Çevresel Tutum ve Katılım ile İkamet Süresi Arasındaki Farklılıklara İlişkin ANOVA ve Kruskal-Wallis Testleri

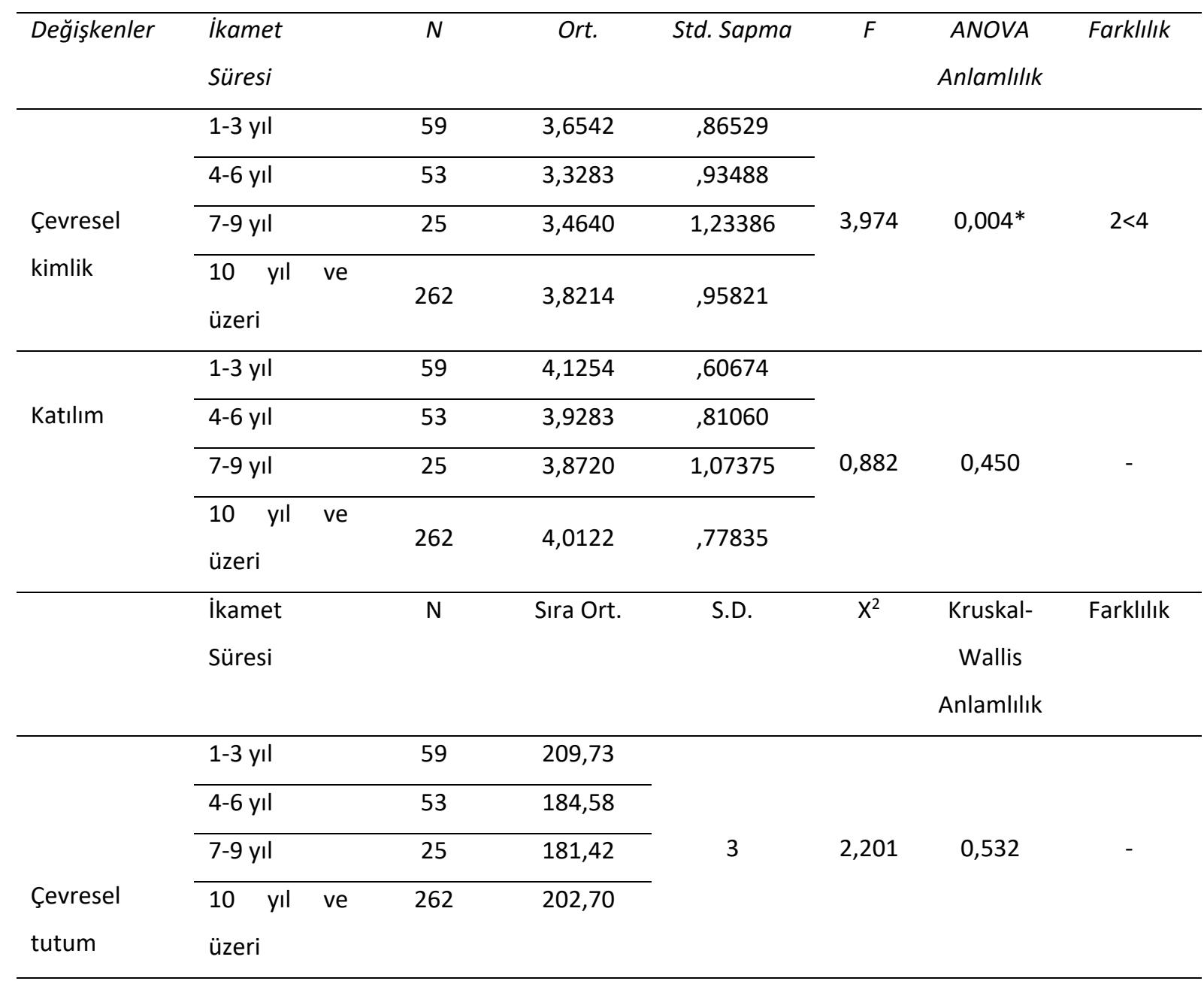

monu olan katılımcıların milli parkları daha çok sahiplenmesi ile açıklanabilir. Diğer yandan katılımın memleket durumuna göre farklılaşmadığı görülmektedir ( $\mathrm{p}=0,983 ; \mathrm{t}=0,021)$. Çevresel tutum ile memleket durumu arasinda fark olup olmad1ğını belirlemek için Mann-Whitney U testi uygulanmıştır. Test sonuçlarına bakıldı̆̆ında, çevresel tutumun memleket durumuna göre anlamlı farklilık göstermediği tespit edilmiştir $(\mathrm{p}=0,168)$.

Çevresel kimlik, çevresel tutum ve katılımın yerel halkın doğal alanları ziyaret etme sıklığına göre farklılı̆̆ının incelendiği analiz Tablo 4 'te verilmiştir. Çevresel kimlik ve katılımın katılımcıların doğal alanları ziyaret etme sıklığına göre farklılığ 1 ANOVA testi ile analiz edilmiş ve 0,05 anlamlılık düzeyinde farklılık tespit edilmiştir. Farklılığın kaynağını belirlemek için Scheffe testi yapılmıştır. Çevresel kimlik ölçeğinde doğal alanları ayda bir ya da daha fazla ziyaret edenlerin yılda bir ya da daha az ziyaret edenlere göre daha duyarlı olduğu sonucuna ulaşılmıştır. Katılım ölçeğinde genel olarak bireylerin doğal alanları ziyaret etme sıklığı arttıkça katılım düzeylerinin de artış gösterdiği belirlenmiştir. Çevresel tutum ölçeğinin normal dağılım sergilememesi nedeniyle farklılık incelemesi için nonparametrik test yöntemi olan Kruskal-Wallis testi uygulanmıştır. Analiz sonucunda, çevresel tutumun doğal alanları ziyaret etme sıklığına göre 0,05 anlam düzeyinde farklılaşttı̆ı tespit edilmiş- 
tir. Doğal alanları yılda bir ya da daha az ziyaret eden ile ayda bir ya da daha fazla ziyaret eden arasında farklılık bulunmaktadır. Grup ortalamalarına göre ayda bir ya da daha fazla doğal alanları ziyaret edenlerin yılda bir ya da daha az doğal alanları ziyaret edenlere göre çevresel tutumlarını daha yüksek olduğu söylenebilir.

Çevresel kimlik, çevresel tutum ile katılımın katılımcıların ikamet süresine göre farklılığın incelendiği analiz sonuçları Tablo 5'te verilmiştir. Katılımın ikamet süresine göre 0,05 anlamlılık düzeyinde farklılık göstermediği tespit edilmiştir. Çevresel kimlik ise katılımcıların ikamet süresine göre farklılık göstermektedir $(\mathrm{p}=0,004)$. Farklılığın kaynağını belirlemek için Games- Howell testi yapılmıştır. İkamet süresi 4-6 yıl olanlar ile 10 yıl ve üzeri olan gruplar arasında anlamlı bir farklılık tespit edilmiştir. Çevresel tutumun normal dağılım sergilememesi nedeniyle farkl1lık incelemesi için Kruskal-Wallis testi uygulanmıştır. Analiz sonucunda, çevresel tutumun ikamet süresine göre farklılık göstermediği tespit edilmiştir.

\section{SONUÇ VE TARTIŞMA}

Kastamonu'da bulunan Ilgaz Dağı Milli Parkı ile ilgili yapılan çalışmalarda parkın rekreaktif faaliyetlerine, destinasyon imajına ve florasina odaklanılırken (Pehlivan 2007; Karaçar 2016), Küre Dağları Mili Parkı'nda ise eko turizm potansiyeli, peyzaj özellikleri ve floraya yönelik birçok çalışma mevcuttur (Görmüş 2012; Oğuz 2015; Meydan 2020). Türkçe alanyazın incelendiğinde milli parklar ya da korunması gereken doğal alanlar özelinde bu üç değişkeni ele alan kapsamlı bir çalışmaya rastlanılmamıştır.

Bu çalışmada, çevresel kimliğin çevresel tutumu yüksek düzeyde pozitif yönlü etkilediği tespit edilmiştir. Bu sonucu doğrular nitelikte çalışmaların alanyazında olduğu gözlemlenmiştir (Stets ve Biga 2003; Hinds ve Spark 2008). Çalışmanın bir diğer sonucu olarak, çevresel tutumun katılımı yüksek düzeyde etkilediği belirlenmiştir. Nitekim Sirivongs ve Tsuchiya (2012) ve Cheng vd. (2019) tutumun katılım üzerinde pozitif yönlü bir etkisi olduğunu tespit etmiştir. Buradan çıarımla bölgede yaşayan yerel halkın koru- nan alanları benimsediği takdirde olumlu bir bakış açısının oluşacağı bu doğrultuda bu alanlarla ilgili koruma çabalarına ve görevlere katılma potansiyelinin yüksek düzeyde olacağı söylenebilir.

Katılımcıların doğa koruma derneğine üye olma durumlarına göre yapılan analizlerde katılım anlamlı farklılık gösterirken, çevresel kimlik ve çevresel tutumun anlamlı farklılık göstermediği belirlenmiştir. Katılımcıların sadece yüzde 10'luk bir kesiminin doğa koruma derneklerine üye olduğu tespit edilmiştir. Bu bağlamda, yerel halkın milli parklarla ilgili gelişimi desteklediği ancak aktif katılımla ilgili çekimser kaldığ görülmüştür. Bu durum Akkuş ve Akkuş'un (2020) çalışmasındaki sonucu destekler niteliktedir. Prévot vd. (2018) doğa koruma derneğine üye olan bireylerin doğal alanları daha sık ziyaret ettiğini belirtmiştir. Ayrıca memleketi Kastamonu olan katılımcıların milli parkları daha çok benimsediği ortaya çıkmıştır. Bu sonuca yakın olarak Yeşilyurt (2019) ve Buzlukçu'nun (2020) çalışmaları gösterilebilir. Bu çalışmalarda Adıyamanlı ve Seferihisarlı olan bireylerin yer kimliğinin, olmayanlara göre daha yüksek düzeyde olduğu görülmüştür. Ayrıca Buzlukçu (2020), bu araştırmanın sonucuna benzer olarak Seferihisarlı bireyler ile sürdürülebilir turizm tutumu arasinda anlamlı bir farklılık olmadığını tespit etmiştir.

Çevresel kimlik, çevresel tutum ve katılımın yerel halkın doğal alanları ziyaret etme sıklığ1na göre anlamlı farklılık gösterdiği saptanmıştır. Çetinkaya (2015) doğa sporlarına katılan bireylerin çevreye karşı daha pozitif tutumlar gösterdiği sonucuna ulaşırken, benzer şekilde Bern ve Simpson (2009) rekreasyonel faaliyetler (yürüyüş, kamp, doğal alan ve park ziyaretleri) ile tutum arasında bir ilişkinin olduğunu ortaya koymuştur. Bu sonuçlar ışı̆̆ında katılımcıların doğal alanları ziyaret etme sıklığ resel kimlik, çevresel tutum ve katılım düzeylerinin artış gösterdiği söylenebilir. Yerel halkın Kastamonu'da ikamet süresine göre çevresel kimlik duygusu anlamlı farklılık gösterirken, katılım ve çevresel tutum için anlamlı bir farklılık tespit edilmemiştir. Yeşilyurt (2019) ve Buzlukçu (2020) ikamet süresi nispeten daha uzun olan bireylerin yer kimliğinin daha yüksek düzeyde olduğu sonucuna ulaşmıştır. 


\section{ÖNERILER}

Bu çalışma Kastamonu sınırları içerisinde yer alan üç milli parka odaklanmıştır. Bu sebeple gelecek çalışmalar farklı il sınırlarında bulunan milli parklara bu modeli uygulayarak, çalışmalar arasında kıyaslama yapabilir. Yine iki ile sınırı bulunan Ilgaz Dağı Milli Parkı'nın Çankırı örneklemi ile çalışılarak Kastamonu verileri ile karşılaştırması yapılabilir.

Milli parkları ziyarete gelen turistler açısından değerlendirmeler yapılabilir. Ziyarete gelen turistlerin hangi algıların onların tutum ve davranışlarında etkili olduğu araştırabilir.

Gelecekteki çalışmalar, yerel halkın tutum ve katılımını etkileyebilecek imaj, hizmet kalitesi ve destinasyon markası gibi değişkenlerle inceleyebilir.

Milli park yöneticileri işbirlikçi yönetim anlayışı ile parkların etkinliği arttırmak için yerel halkın sürece katılımını sağlayabilir.

\section{KAYNAKÇA}

Abun, D. ve Racoma, A. (2017). Environmental Attitude and Environmental Behavior of Catholic Colleges' Employees in Ilocos Sur, Philippines, Texila International Journal of Academic Research, 4 (1): 23-52.

Akkuş, Ç. ve Akkuş, G. (2020). Yerel Halkın Kültürel Miras1 Korumaya Katılma Tutumu ve Turizmi Destekleme Davranışının Demografik Özelliklerine Göre İncelenmesi, Turkish Studies - Social, 15 (3): 887-904.

Altunışık, R., Çoşkun, R., Bayraktaroğlu, S. ve Yıldırım, E. (2012). Sosyal Bilimlerde Araştırma Yöntemleri SPSS Uygulamalı. (Geliştirilmiş yedinci baskı). Sakarya: Sakarya Yayıncilik.

Bagozzi, R. P. ve Dholakia, U. M. (2002). Intentional Social Action in Virtual Communities, Journal of Interactive Marketing, 16 (2): 2-21.

Bakır, S. (2019). Türkiye'de Küreselleşme Süreci ve Korunan Alanlar Üzerine Etkisi: Datça Bozburun Özel Çevre Koruma Bölgesi (Basılmamış Yüksek Lisans Tezi). İzmir: Dokuz Eylül Üniversitesi Fen Bilimleri Enstitüsü.

Bello, F. G., Carr, N. ve Lovelock, B. (2016). Community Participation Framework for Protected Area-Based Tourism Planning, Tourism Planning \& Development, 13 (4): 469485.

Bern, G. N. ve Simpson, S. (2009). Outdoor Recreation Participation and Environmental Concern: A Research Summary, Journal of Experiential Education, 32 (1), 79-91.

Buzlukçu, C. (2020). Yerel Halkın Yer Kimliği, Topluluğa Bağlılığ1, Sürdürülebilir Turizm Tutumu, Turizmin Gelişimini Destekleme Tutumu ve Yaşam Memnuniyeti İlişkisi (Basılmamış Doktora Tezi). Balıkesir Üniversitesi Sosyal Bilimler Enstitüsü.
Cheng, T. M., Wu, H. C., Wang, J. T. M. ve Wu, M. R. (2019). Community Participation As a Mediating Factor on Residents' Attitudes Towards Sustainable Tourism Development and Their Personal Environmentally Responsible Behaviour, Current Issues in Tourism, 22 (14): 1764-1782.

Clayton, S. (2003). Environmental Identity: A Conceptual and an Operational Definition. İçinde Clayton. S. ve Opotow. S. (Editörler). Identity and The Natural Environment The Psychological Significance of Nature (ss. 45-65). Boston: MIT Press.

Clayton, S. ve Opotow, S. (2003). Identity and The Natural Environment: The Psychological Significance of Nature. Boston: MIT Press.

Çetinkaya, G. (2015). Doğa Sporlarına Katılım Çevre Tutumunu Etkiler Mi? Üniversite Öğrencileri Üzerine Bir Araştırma, Ankara Üniversitesi Spor Bilimleri Fakültesi, 13 (2), 137-142.

Doğa Koruma ve Milli Parklar Müdürlügü (2020), http://ilgazdagi.tabiat.gov.tr/, Erişim tarihi: 30 Ekim 2020.

Eliam, E. ve Trop, T. (2012). Environmental Attitudes and Environmental Behavior-Which Is the Horse and Which Is the Cart?, Sustainability, 4 (12): 2210-2246.

Erdoğan, N. (2003). Çevre ve (Eko)turizm. Ankara: Erk Yayıncilik.

Ezebilo, E. E. ve Mattsson, L. (2010). Socio-Economic Benefits of Protected Areas as Perceived by Local People Around Cross River National Park, Nigeria, Forest Policy and Economics, 12: 189-193.

Gifford, R. ve Sussman, R. (2012). Environmental Attitudes. İçinde; Clayton, S. D. (Editör). The Oxford Hanbook of Environmental and Conservation Psychology. (ss.65-80). Büyük Britanya: Oxford University Press.

Görmüş, S. (2012). Korunan Alanlarda Peyzaj Karakter Analizi: Kastamonu-Bartın Küre dağları Milli Parkı Örneği. (Basılmamış yüksek lisans tezi). Ankara: Ankara Üniversitesi Fen Bilimleri Enstitüsü.

Gürbüz, S. (2019). Amos ile Yapısal Eşitlik Modellemesi. Ankara: Seçkin Yayıncılık.

Gürbüz, S. ve Şahin, F. (2018). Sosyal Bilimlerde Araştırma Yöntemleri. Ankara: Seçkin Yayıncılık.

Hair, J. F., Black, W. C., Babin, B. J. ve Anderson, R. E. (2009). Multivariate Data Analysis (Yedinci baskı). ABD: Prentice Hall.

Hinds, J. ve Sparks, P. (2008). Engaging with The Natural Environment:The Role of Affective Connection and Identity, Journal of Environmental Psychology, 28: 109120.

Karaçar, E. (2016). Rekreatif Faaliyetlerde Çevreye Yönelik Tutumların ve Destinasyon İmajının Tekrar Ziyaret Niyetine Etkisi: Ilgaz Dağı Milli Parkı Örneği. (Basılmamış doktora tezi). Ankara: Gazi Üniversitesi Sosyal Bilimler Enstitüsü.

Kashima, Y., Paladino, A. ve Margetts, E. A. (2014). Environmentalist Identity and Environmental Striving, Journal of Environmental Psychology, 38: 64-75. 
Kempton, W. ve Holland, D. (2003). Identity and Sustained Environmental Practice. İçinde; S. Clayton \& S. Opotow (Editörler.), Identity and The Natural Environment The Psychological Significance of Nature (ss. 317-341). Boston: MIT Press.

Kutay Karaçor, E. ve Akçam, E. (2016). Yer Kimliği, Toplum Duyusu ve Çevresel Tutum Değişkenleri Arasındaki Kavramsal İlişkinin Yapısal Eşitlik Modellemesi ile Açıklanması, Turkish Journal of Forestry, 17 (2): 194-200.

Küre Dağları Milli Parkı. (2020), https://www.kdmp.gov.tr/ kure-daglari-milli-parki, Erişim tarihi: 30.10.2020.

Lake, W. (2019). Conflict in the Consumer Identity: The Coexistence and Consequences of Environmental Identity and Material Identity (Basılmamıs doktora tezi). The University of Adelaide Business School.

Lewis, J. (2015). Preserving and Maintaining the Concept of Letchworth Garden City, Planning Perspectives, 30 (1): 153-163.

Meydan, K. (2020). Küre Dağları Milli Parkı'nın Kastamonu İ Sınırlarında Ekoturizm Potansiyelinin Ecos Yöntemi ile Belirlenmesi (Basılmamış yüksek lisans tezi). Kastamonu Üniversitesi Fen Bilimleri Enstitüsü.

Milfont, T.L. ve Duckitt, J. (2004). The Structure of Environmental Attitudes: A First-And Second-Order Confirmatory Factor Analysis, Journal of Environmental Psychology, 24 (3): 289-303.

Oğuz, M. (2015). Küre Dağları Milli Parkı'nın Kastamonu İli Sinırlarında Kalan Bölümünün Makrofungus Florası. (Basılmamış yüksek lisans tezi). Bartın Üniversitesi Fen Bilimleri Enstitüsü.

Pehlivan, G. (2007). Ilgaz Dağı Milli Parkı Florası (basılmamıs yüksek lisans tezi). Ankara: Gazi Üniversitesi Fen Bilimleri Enstitüsü.

Prévot, A.C., Clayton, S. ve Mathevet, R. (2018). The Relationship of Childhood Upbringing and University Degree Program to Environmental Identity: Experience in Nature Matters, Environmental Education Research, 24 (2): 263-279.

Schultz, P.W., Shriver, C., Tabanico, J.J. ve Khazian, A.M. (2004). Implicit Connections with Nature, Journal of Environmental Psychology, 24: 31-42.

Shrestha, R. ve Alavalapati, J. R. (2006). Linking Conservation and Development: An Analysis of Local People's Attitude towards Koshi Tappu Wildlife Reserve, Nepal, Environment, Development and Sustainability, 8: 69-84.
Sirivongs, K. ve Tsuchiya, T. (2012). Relationship between Local Residents' Perceptions, Attitudes and Participation Towards National Protected Areas: A Case Study of Phou Khao Khouay National Protected Area, Central Lao PDR, Forest Policy and Economics, 21: 92-100.

So, K. F. K., King, C., Sparks, B. A. ve Wang, Y. (2013). The Influence of Customer Brand Identification on Hotel Brand Evaluation and Loyalty Development, International Journal of Hospitality Management, 34: 31-41.

Stets, J. E. ve Biga, C. F. (2003). Bringing Identity Theory into Environmental Sociology, Sociological Theory, 21: 398423.

Su, L., Huang, S. (S). ve Pearce, J. (2019). Toward A Model of Destination Resident-Environment Relationship: The Case of Gulangyu, China, Journal of Travel \& Tourism Marketing, 36 (4): 469-483.

Tarım ve Orman Bakanlığı, (2021). https://www.tarimorman. gov.tr/DKMP/Menu/27/Milli-Parklar, Erişim tarihi: 21 Ocak 2021

Teeroovengadum, V. (2019). This Present Research Provides Evidence That Environmental Identity Has a Major Role to Play in Explaining The Behaviours of Tourists towards Ecotourism Products and Service, Tourism Review, 74 (2): 280-292.

Tosun, C. (2000). Limits to Community Participation in The Tourism Development Process in Developing Countries, Tourism Management, 21(6): 613-633.

Tukamushaba, E. K. ve Okech, R. N. (2011). Tourism Training and Education, Community Empowerment and Participation in Tourism Planning and Development. A Case of Uganda, Journal of Tourism, 12 (1): 78-101.

Wang, Q. ve Yamamoto, H. (2009). Local Residents' Perception, Attitude and Participation Regarding Nature Reserves of China: Case Study of Beijing Area, Journal of Forest Planning, 14 (2): 67-77.

Van der Werff, E., Steg, L. ve Keizer, K. (2013). The Value of Environmental Self-Identity: The Relationship Between Biospheric Values, Environmental Self-Identity and Environmental Preferences, Intentions and Behaviour, Journal of Environmental Psychology, 34: 55-63.

Yeşilyurt, H. (2019). Yerel Halkın Turizm Gelişimine Yönelik Desteğinde Yer Kimliği ve Yer İmajının Rolü: Adıyaman Örneği (basılmamış doktora tezi). İzmir: Dokuz Eylül Üniversitesi Sosyal Bilimler Enstitüsü. 


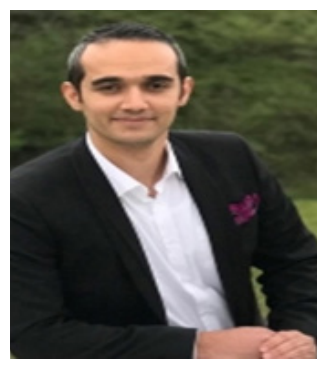

Çetin AKKUŞ

Akdeniz Üniversitesi Turizm Işletmeciliği ve Otelcilik Yüksekokulu’ndan Konaklama Işletmeciliği Bölümü'nden mezun oldu (2009). Yüksek lisans derecesini Atatürk Üniversitesi'nden İ̧̧letme Ana Bilim Dalı'ndan (2012), doktora derecesini de Atatürk Üniversitesi'nden Turizm İsletmeciliği ve Otelcilik Ana Bilim Dalı'ndan aldı (2016). Atatürk Üniversitesi'nde araştırma görevlisi olarak çalışmaya başladı (2010). Aynı üniversitede Dr. Ö̈̆r. Üyesi olarak atandı (2017). Halen Kastamonu Üniversitesi Turizm Fakültesi'nde görev yapmaktadır. Temel çalışma alanları turizm pazarlaması ve turist davranışıdır.

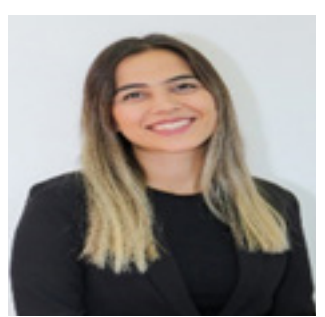

\section{Selda YORDAM}

Eskişehir Osmangazi Üniversitesi Turizm ve Otel İşletmeciliği Yüksekokulu'ndan Turizm ve Otel İşletmeciliği Bölümü'nden mezun oldu (2016). Yüksek lisans derecesini Eskişehir Osmangazi Üniversitesi'nden Turizm İşletmeciliği Ana Bilim Dalı'ndan (2019) aldı. Kastamonu Üniversitesi'nde araştırma görevlisi olarak çalışmaya başladı (2019). Halen Kastamonu Üniversitesi Turizm Fakültesi'nde görev yapmaktadır. Temel çalışma alanları turizm pazarlaması ve alternatif turizmdir. 